\title{
ANALYSIS OF SELECTED PRE-CONCEPTS OF TECHNICAL EDUCATION OF 5. CLASSES OF PRIMARY SCHOOL
}

\author{
Aleš BARTOŇ
}

\begin{abstract}
The paper deals presentation of partial results of a qualitative and quantitative diagnosis of selected pre-concepts of technical education of primary school children. Pupils of fifth class from České Budéjovice took part of research. The acquired data of pre-concepts and its integration were processed from the qualitative as wel as quantitative point of view in the spere of technical education.
\end{abstract}

Key words: pre-concept, technical education, scholars subjekt matter, teachers part of constructivism education.

\section{DIAGNOSTIKA VYBRANÝCH PREKONCEPTŮ K TECHNICKÉ VÝCHOVĚ ŽÁKŮ 5. TŘÍD ZŠ}

Resumé: Tento př́spěvek se zabývá prezentací dílčich cílů výzkumu kvantitativní a kvalitativní diagnostiky vybraných prekoncepti̊ k technice na primární škole. Výzkumu se zúčastnili žáci 5. tř́d základních škol v Českých Budějovicích. Dotazníkovou metodou a kognitivními mapami byly zjištěny a následně zpracovány údaje o prekonceptech a jejich zastrukturování, z hlediska kvalitativního i kvantitativního, voblasti technické výchovy.

Klíčová slova: prekoncept, technické vzdělávání, žákovo pojetí učiva, role učitele v konstruktivisticky pojaté výuce.

\section{1 Úvod}

Na základě učebního procesu si každý žák vytváŕí své vlastní prekoncepty, to je východiskem konstruktivisticky pojaté výuky, protože zde má prekoncept dominantní postavení a celý proces učení z něj vychází (1). Často se stává, že žák své názory, představy i při velmi kvalitním výkladu nového učiva nerad mění. Vytvář́ tak s novým učivem určitou symbiózu a dosavadní individuální koncepce žáka nezmizí, to je velmi důležité zjištění z hlediska současného vědeckého poznání, avšak ne z hlediska pojetí samotného dítěte, označujeme ho jako miskoncepce (2). Žákovské prekoncepty se spolu kumulují a vytvářejí mentální mapy, které nám umožňují nahlédnout do dětského pojetí světa (3). V současné době je žádoucí při samotné výuce využívat metody založené na práci s prekoncepty. Bertrand, Y. uvádí dva základní směry, mezi které patří „vyjadřování prekonceptů“ a „,boj proti prekonceptům“ (4). Přri vyjadřování prekonceptů učitel vytváří výchozí situaci $\mathrm{s}$ cílem přivést žáka $\mathrm{k}$ vyjádření jeho spontánního chápání skutečnosti. Tím se staví do protikladů různé reprezentace. Následně žák získává odstup od svého vlastního pojetí, dochází $\mathrm{k}$ rozvinutí a někdy i k reorganizaci jeho pojetí. V druhém směru učitel zpochybňuje žákův prekoncept, či staví v dialogu protikladné názory.
Výsledkem je pak žákovo zjištění, že jeho prekoncepty jsou velmi vzdáleny od vědeckého poznání reality (4), (5). Zmiňované žákovské prekoncepty lze diagnostikovat v kognitivní dimenzi. Zde je nejčastěji využíváno metody didaktických testů. V afektivní dimenzi zachycujeme určitou emoci - reakci, použít lze metodu dotazníku (6), (7). Následuje zastrukturování, u kterého hrají důležitou roli pojmové mapy (8). K plasticitě uvádí Čáp, J. a Mareš, J. jako vhodnou diagnostickou metodu rozhovor (8). Tato metodologie byla využita rovněž při realizaci předkládaného výzkumu (9).

\section{Cíle a metody výzkumu}

Hlavním cílem výzkumu bylo zjistit, zda pojmy, které jsou předmětem šetření u žáků, tedy žákovské pojetí prekonceptů, jsou ve shodě s vymezením učiva ve vzdělávacím kurikulu, konkrétně reprezentovaném Rámcovým vzdělávacím programem pro ZV. Dílčím cílem bylo u prekonceptů zjistit kvalitativní a kvantitativní úroveň kognitivní a afektivní dimenze a míry zastrukturování, na základě analýzy odpovědí z dotazníků. Pro výzkum byly stanoveny tyto prekoncepty: dřevo, ruční brzda, pevnost, pružnost, lepení, řezání, recyklace materiálu, bezpečnost při práci. 
3 Popis výzkumného vzorku a charakteristika použitých výzkumných měřících nástrojů

Cílovou skupinou dotazovaných byli žáci 5 . tříd, v prvním pololetí školního roku 2008/2009, a to ze ZŠ Kubatova v Českých Budějovicích, 5. A (20 žáků), 5. B (18 žáků) a ZŠ Grünwaldova v Českých Budějovicích, 5. C (23 žáků). Celkový počet dotazovaných žáků byl 61. Diagnostika prekonceptů byla realizována pomocí výzkumných nástrojů, které bylo nutno nově zkonstruovat, nebot' v oblasti techniky na primární škole dosud nebyl podobný výzkum v ČR dosud realizován ani publikován. Inspirací byly především zdroje $(6,10,11,12,13)$. Vybrané prekoncepty byly posuzovány v kognitivní a afektivní rovině, byl určován stupeň jejich zastrukturování $\mathrm{v}$ individuálních kognitivních mapách žáků. Ke všem třem oblastem musel být vytvořen speciální měřící nástroj. Pro kognitivní dimenzi byl volen dotazník nedokončených vět, pro afektivní dimenzi pětistupňová posuzovací škála Likertova typu, pro zastrukturování bylo vytvořeno několik modelů odstupňovaných kognitivních map pro každý prekoncept. Dále byly formulovány, na základě otázek, čtyři hypotézy výzkumu.

\section{Formulace hypotéz}

Otázka: Existuje u žáků vztah mezi pojmy dřevo a pevnost v kognitivní rovině?

Otázka: Existuje u žáků určitý vztah v afektivní rovině mezi pojmy lepení a řezání?

Otázka: Existuje u žáků vztah v kognitivní rovině mezi pojmy recyklace materiálu bezpečnost při práci?

Otázka: Existuje u žáků určitý vztah v kognitivní rovině mezi pojmy pevnost a pružnost?

\section{Testování hypotéz}

Testování hypotézy $\mathrm{H}_{1}$

Formulace nulové a alternativní hypotézy

$\mathrm{H}_{0}$ : Mezi pojmy dřevo a pevnost není u žáků vztah v kognitivní roviné.
$\mathrm{H}_{\mathrm{A}}$ : Mezi pojmy dřevo a pevnost je u žáků vztah v kognitivní roviné.

$\mathrm{Na}$ základě kognitivního dotazníku byl u čtvrtiny dotazovaných zaznamenán vztah v kognitivní rovině mezi pojmy dřevo a pevnost, viz. tabulka č. 1. Z vyhodnocení vyplývá, že nelze běžnými použitými metodami rozhodnout o přijetí hypotézy. Č́stečně byla potvrzena nulová hypotéza. Lze konstatovat, že u respondentů tohoto výzkumu mezi pojmy dřevo a pevnost je u 1⁄4 žáků vztah v kognitivní rovině.

Tabulka 1: Kognitivní rovina: Dřevo.

\begin{tabular}{|l|l|l|l|}
\hline Tř́da & $\begin{array}{l}\text { Počet } \\
\text { žáků }\end{array}$ & $\begin{array}{l}\text { Počet } \\
\text { odpovědí } \\
\text {,dřevo“ }\end{array}$ & $\begin{array}{l}\text { Procenta } \\
\text { odpovědí } \\
\text { „dřevo“ }\end{array}$ \\
\hline $\begin{array}{l}\text { 5.A ZŠ } \\
\text { Kubatova }\end{array}$ & $\mathbf{2 0}$ & $\mathbf{4}$ & $\mathbf{2 0 , 0 0 \%}$ \\
\hline $\begin{array}{l}\text { 5.B ZŠ } \\
\text { Kubatova }\end{array}$ & $\mathbf{1 8}$ & $\mathbf{5}$ & $\mathbf{2 7 , 7 7 \%}$ \\
\hline $\begin{array}{l}\text { 5.C ZŠ } \\
\text { Grünwaldova }\end{array}$ & $\mathbf{2 3}$ & $\mathbf{3}$ & $\mathbf{1 3 , 0 5 \%}$ \\
\hline Celkem & $\mathbf{6 1}$ & $\mathbf{1 2}$ & $\mathbf{1 9 , 6 7 \%}$ \\
\hline
\end{tabular}

Testování hypotézy $\mathbf{H}_{2}$

Formulace nulové a alternativní hypotézy

$\mathrm{H}_{0}$ : Mezi pojmy lepení a řezání není u žáků vztah $v$ afektivní rovinè.

$\mathrm{H}_{\mathrm{A}}$ : Mezi pojmy lepení a řezání je u žáků vztah $v$ afektivní roviné.

Vztah mezi těmito pojmy byl zaznamenán na základě vyhodnocení dat z afektivní škály. U žáků byl zaznamenán velmi silný afektivní vztah k oběma prekonceptům, který je však negativní, navíc byl patrný ve stejné míre u chlapců i dívek. Tento stav lze interpretovat zvlášt' pro chlapce i dívky (9). Platnost hypotézy je patrná z tabulky č. 2, průměrná afektivní hodnota obou prekonceptů je 2,93. Na základě této analýzy bylo konstatováno, že u respondentů tohoto výzkumu mezi pojmy lepení a řezání je u žáků negativní vztah v afektivní rovině. Byla přijata alternativní hypotéza a odmítnuta nulová.

Tabulka 2: Afektivní rovina: Lepení a řezání.

\begin{tabular}{|c|c|c|c|c|c|}
\hline \multirow[t]{2}{*}{ Třída } & \multicolumn{2}{|c|}{ Lepení } & \multicolumn{2}{|c|}{ Řezání } & \multirow{5}{*}{$\begin{array}{l}\text { Průměrné } \\
\text { afektivní } \\
\text { hodnocení za } \\
\text { všechny hodnoty }\end{array}$} \\
\hline & Dívky & Chlapci & Dívky & Chlapci & \\
\hline 5.A ZŠ Kubatova ČB & 2,5 & 2,75 & 2,62 & 2,33 & \\
\hline 5.B ZŠ Kubatova ČB & 2,87 & 3 & 3,57 & 3,44 & \\
\hline 5.C ZŠ Grünwaldova & 2,71 & 3,26 & 3,62 & 2,53 & \\
\hline Průměrné afektivní hodnocení & 2,70 & 3,00 & 3,27 & 2,76 & \\
\hline $\begin{array}{l}\text { Prům. afekt. hodno. za jed. } \\
\text { pojmy }\end{array}$ & \multicolumn{2}{|l|}{2,85} & \multicolumn{2}{|l|}{3,01} & 2,93 \\
\hline
\end{tabular}


Testování hypotézy $\mathrm{H}_{3}$

Formulace nulové a alternativní hypotézy. $\mathrm{H}_{0}$ : Mezi pojmy recyklace materiálu a bezpečnost prí práci, není u žáků vztah v kognitivní roviné. $\mathrm{H}_{\mathrm{A}}$ : Mezi pojmy recyklace materiálu a bezpečnost pri práci, je u žákủ vztah v kognitivní rovině.
Velmi markantní byl rozdíl v chápání těchto pojmů. Pojem ,recyklace materiálu“ se prokázal být dětem velmi dobře známý a ve většině prípadů ho byly schopny diagnostikovat bez problému (9). Zajímavé je, že i rozdíl v odpovědích chlapců a dívek byl v podstatě mizivý, viz. tabulka číslo 3.

Tabulka 3: Kognitivní rovina: 5. A, 5. B, ZŠ Kubatova, 5. C, ZŠ Grünwaldova.

\section{V dnešní době se běžně recykluje materiál a slovo recyklace znamená:}

\begin{tabular}{|c|c|c|c|c|c|c|}
\hline & dívky & $\%$ & chlapci & $\%$ & celkem & $\%$ \\
\hline Odpověděli & 18 & $29,50 \%$ & 34 & $55,73 \%$ & 52 & $85,24 \%$ \\
\hline Neodpověděli & 6 & $09,83 \%$ & 3 & $04,91 \%$ & 9 & $14,75 \%$ \\
\hline Odpovědi & dívky & $\%$ & chlapci & $\%$ & celkem & $\%$ \\
\hline $\begin{array}{l}\text { Z popsaného papíru se udělá toaletní papír. } \\
\text { Staré přeměnit na nové.Ze zničeného odpadu se } \\
\text { může udělat nová věc. }\end{array}$ & 16 & $26,22 \%$ & 30 & $49,18 \%$ & 46 & $75,40 \%$ \\
\hline $\begin{array}{l}\text { Třídíme odpad, který se pak znovu obnovuje. } \\
\text { Smršt'ovat něco k sobě. Likvidace. Drtit. }\end{array}$ & 2 & $03,27 \%$ & 4 & $06,55 \%$ & 6 & $09,83 \%$ \\
\hline
\end{tabular}

Naproti tomu u pojmu ,bezpečnost při práci“ byl zaznamenán opačný trend. Jejich představy v chápání tohoto pojmu jsou rozporuplné a tudíž lze usuzovat na prrítomnost miskoncepce nebo existenci pojmů mentálně úplně izolovaných. To potvrzuje tabulka číslo 4, ze které je patrné, že jen malé procento dotazovaných bylo schopno vystihnout podstatu daného termínu. Některé odpovědi by sice mohly být chápány za určitých okolností jako možné, ale jejich př́ípadné dovysvětlení, či upřssnění vždy chybělo.

Tabulka 4: Kognitivní rovina: 5. A, 5. B, ZŠ Kubatova, 5. C, ZŠ Grünwaldova.

\begin{tabular}{|c|c|c|c|c|c|c|}
\hline \multicolumn{7}{|c|}{ Bezpečnost při práci znamená například, že při vykonávání nějaké...: } \\
\hline & dívky & $\%$ & chlapci & $\%$ & celkem & $\%$ \\
\hline Odpověděli & 22 & $36,06 \%$ & 29 & $47,54 \%$ & 51 & $83,60 \%$ \\
\hline Neodpověděli & 3 & $04,91 \%$ & 7 & $11,47 \%$ & 10 & $16,39 \%$ \\
\hline Odpovědi & dívky & $\%$ & chlapci & $\%$ & celkem & $\%$ \\
\hline $\begin{array}{l}\text { Ohrožovat ostatní lidi kolem sebe. } \\
\text { Nebýt opilý, ani pod vlivem drog. ... . }\end{array}$ & 3 & $04,91 \%$ & 7 & $11,47 \%$ & 10 & $16,39 \%$ \\
\hline $\begin{array}{l}\text { Používat nože, zápalky. Ŕíkat sprostá slova na } \\
\text { Reditele. } \\
\text { Běhat. Se ulejvat. Dávat pozor.Držet nůž v ruce. } \\
\text { Řezat. Jíst. Pouštět pilu. ..... }\end{array}$ & 19 & $31,14 \%$ & 22 & $36,06 \%$ & 41 & $67,20 \%$ \\
\hline
\end{tabular}

To lze interpretovat jako pouhou deklamaci odborných pojmů, které jsou poživány žáky ovšem bez znalosti jejich významu.

Kognitivní vztah mezi pojmy „recyklace materiálu“ a „bezpečnost při práci“ nebyl zaznamená, a proto byla odmítnuta alternativní hypotéza a prrijata nulová. U respondentů tohoto výzkumu mezi pojmy recyklace materiálu a bezpečnost při práci, není u žáků vztah v kognitivní rovině.
Zajímavým výsledkem vyhodnocení afektivní škály v oblasti těchto termínů je, že „bezpečnost při práci“ byla žáky $\mathrm{v}$ průměru podstatně lépe hodnocena, než ,recyklace materiálu“. To přisuzujeme tomu, že termín recyklace materiálů může být pro děti nový, termín, se kterým se ve škole př́liš nesetkaly, nebo nebyl hlouběji rozebírán. To je patrné z tabulky číslo 5. 
Tabulka 5: Afektivní rovina: Recyklace materiálu a bezpečnost prri práci.

\begin{tabular}{|l|l|l|l|l|}
\hline \multirow{2}{*}{ Třída } & \multicolumn{2}{l|}{$\begin{array}{l}\text { Recyklace } \\
\text { materiálu }\end{array}$} & \multicolumn{2}{l|}{$\begin{array}{l}\text { Bezpečnost při } \\
\text { práci }\end{array}$} \\
\cline { 2 - 5 } & Dívky & Chlapci & Dívky & Chlapci \\
\hline $\begin{array}{l}\text { 5.A ZŠ } \\
\text { Kubatova } \\
\text { ČB }\end{array}$ & $\mathbf{2 , 5 7}$ & $\mathbf{2 , 1 8}$ & $\mathbf{1 , 2 5}$ & $\mathbf{1 , 5 8}$ \\
\hline $\begin{array}{l}\text { 5.B ZŠ } \\
\text { Kubatova } \\
\text { ČB }\end{array}$ & $\mathbf{2 , 3 3}$ & $\mathbf{2}$ & $\mathbf{1 , 3 7}$ & $\mathbf{1 , 3 3}$ \\
\hline $\begin{array}{l}\text { 5.C ZŠ } \\
\text { Grünwaldova }\end{array}$ & $\mathbf{1 , 6 2}$ & $\mathbf{2 , 8 6}$ & $\mathbf{1 , 2 5}$ & $\mathbf{2 , 6 6}$ \\
\hline $\begin{array}{l}\text { Průměrné } \\
\text { afektivní } \\
\text { hodnocení }\end{array}$ & $\mathbf{2 , 1 7}$ & $\mathbf{2 , 3 4}$ & $\mathbf{1 , 2 9}$ & $\mathbf{1 , 8 5}$ \\
\hline $\begin{array}{l}\text { Prům. afe. } \\
\text { hod. za jed. } \\
\text { pojmy }\end{array}$ & $\mathbf{2 , 2 5}$ & $\mathbf{1 , 5 7}$ & \\
\hline
\end{tabular}

$\mathrm{H}_{0}$ : Mezi pojmy pevnost a pružnost neni u žáki̊ vztah $v$ kognitivní roviné.

$\mathrm{H}_{\mathrm{A}}$ : Mezi pojmy pevnost a pružnost je u žáki̊ vztah v kognitivní roviné.

Pouze u pojmu dřevo a s ním pojmů souvisejících, byl zaznamenán vztah v kognitivní rovině mezi prekocnepty pevnost a pružnost, a to pouze v některých prrípadech, viz. tabulka číslo 6 . Pevnost jako, vlastnost, byla nejčastěji přisuzována kovům, horninám a nerostům. Naproti tomu pružnost byla přisuzována nejčastěji pojmům jako pružina a guma (9).

Kognitivní vztah mezi pojmy ,pevnost a pružnost" nebyl zaznamenán, a proto byla odmítnuta alternativní hypotéza přijata nulová. Lze konstatovat, že u respondentů tohoto výzkumu mezi pojmy pevnost a pružnost není u žáků vztah v kognitivní rovině.

Testování hypotézy $\mathbf{H}_{4}$

Formulace nulové a alternativní hypotézy

Tabulka 6: Kognitivní rovina: Pevnost a pružnost, jako společná vlastnost.

\begin{tabular}{|l|l|l|l|l|l|}
\hline Tř́da & $\begin{array}{l}\text { Počet } \\
\text { žáků }\end{array}$ & $\begin{array}{l}\text { Pružnost } \\
\text { "dřevo“ }\end{array}$ & $\begin{array}{l}\text { Pevnost } \\
\text { „dřevo“ }\end{array}$ & $\begin{array}{l}\text { Odpovědi „dřevo“ve } \\
\text { stejném poměru k } \\
\text { prekonceptům }\end{array}$ & $\begin{array}{l}\text { \% odpovědí } \\
\text { ve stejném } \\
\text { poměru }\end{array}$ \\
\hline 5.A ZŠ Kubatova ČB & $\mathbf{2 0}$ & $\mathbf{2}$ & $\mathbf{4}$ & $\mathbf{2}$ & $\mathbf{0 3 , 2 7 \%}$ \\
\hline 5.B ZŠ Kubatova ČB & $\mathbf{1 8}$ & $\mathbf{2}$ & $\mathbf{4}$ & $\mathbf{2}$ & $\mathbf{0 3 , 2 7 \%}$ \\
\hline 5.C ZŠ Grünwaldova & $\mathbf{2 3}$ & $\mathbf{6}$ & $\mathbf{3}$ & $\mathbf{3}$ & $\mathbf{0 4 , 9 1 \%}$ \\
\hline Celkem & $\mathbf{6 1}$ & $\mathbf{1 0}$ & $\mathbf{1 1}$ & $\mathbf{7}$ & $\mathbf{1 1 , 4 7 \%}$ \\
\hline
\end{tabular}

\section{Další interpretace výsledků výzkumu}

Výsledky výzkumu vafektivní oblasti přinesly zajímavé informace. Nejlépe byly u chlapců a dívek hodnoceny prekoncepty „pevnost“ a „dřevo“. Dívky „dřevo“ hodnotily průměrnou afektivní škálou 1,91 a pevnost 1,95. Chlapci hodnotili tyto prekoncepty podobným způsobem, s hodnotami 1,81 a 1,80. Vztah mezi „dřevem“ a „pevnosti““ dokazuje $\mathrm{i}$ hypotéza $\mathrm{H}_{1}$, u které byla ověřena platnost nulové. To, že mají chlapci blízký vztah k prekonceptu dřevo, dále potvrzuje i část výsledků z hypotézy $\mathrm{H}_{2}$ (9). I v hypotéze $\mathrm{H}_{4}$ přisuzovali dotazování dřevu pevnost a pružnost jako vlastnost. Nepřehlédnutelným faktem je, že prekoncepty lepení a řezání zaujímají podstatně horších výsledků, než ostatní prekoncepty, viz. graf číslo 1.

Je zajímavé, že na první otázku z kognitivního dotazníku: „Na výrobu různých předmětů používá člověk dřevo z těchto stromů:“, jako odpověd’ žáci nejčastěji uvedli „smrk“, „buk“,

Graf 1 - Afekt. Rov.: Prům. afekt. hodnoty

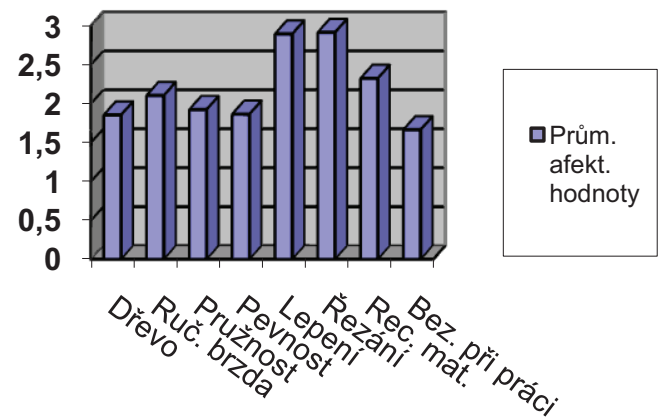

„dub“, a to bez ohledu na pohlaví. Sjednocení názorný další přehled všech odpovědí poskytuje graf číslo 2 . Tento výsledek prrisuzujeme tomu, že nejbližší okolí respondentů nemusí být $\mathrm{v}$ této problematice dostatečně fundováno a děti se ve škole při výuce prvouky setkají s těmito stromy, kromě jiných, pravděpodobně nejdřive. 


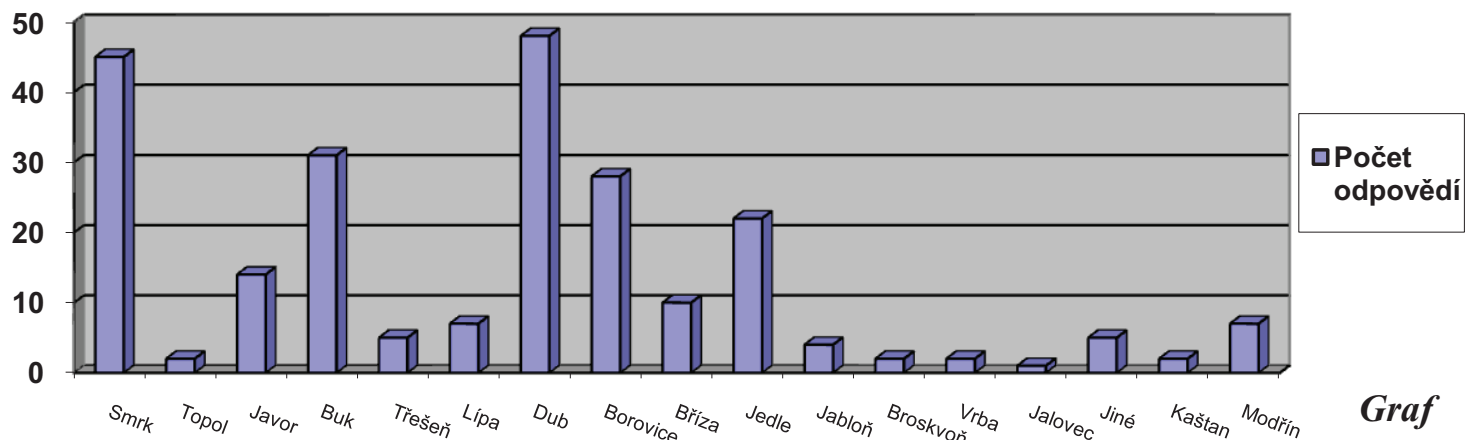

2: Kognitivní rovina: Typy odpovédí $k$ otázce číslo 1.

Překvapivou výpověd' nám poskytla tato otázka: „Ze svého okolí znám tyto materiály, které je možno pevně spojovat lepením:“, největšího procentuálního zastoupení dosáhly pojmy dřevo a papír, to ovšem považujeme za zcela nedostačující. Žák 5 . tř́ídy by měl mít podstatně širší přehled, viz. graf číslo 3 .

Graf 3: Kognitivní rovina: Typy odpovědi k otázce číslo 9

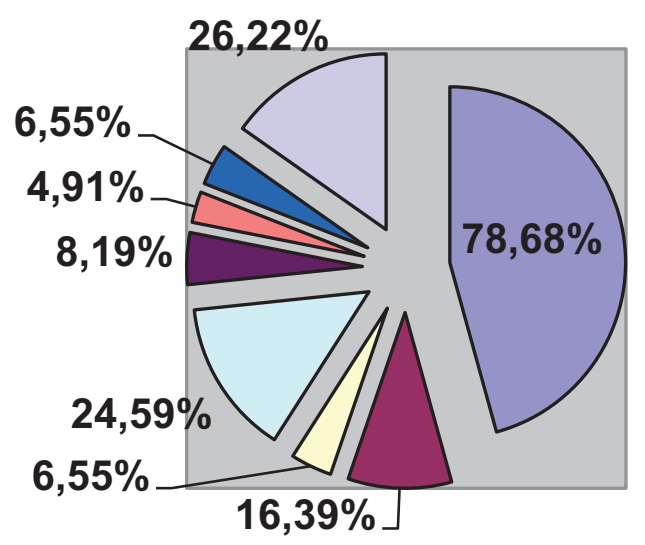

Na vyplňování kognitivních map se podíleli žáci ve skupinách po třech, či čtyřech, v závislosti na počtu žáků ve trî́dě. I přesto žáci neprokázali, že se v mapách orientují, a že jejich strukturace prekonceptů odpovídá vyplněným kognitivním mapám. V některých případech se objevovaly celé nevyplněné stránky těchto map,

$\square^{\text {Papír }}$
$\square^{\text {Plast }}$
$\square^{\text {Modely }}$
$\square^{\text {Drevo }}$
$\square^{\text {Nesmyslné odpovědi }}$
$\square^{\text {Keramika }}$
$\square^{\text {Textil }}$
$\square^{\text {Ostatní }}$

viz obr. č. 1. Důvody tohoto jevu lze spatřovat v několika rovinách, např. nezvyklost práce s grafickým strukturováním učiva, nesystematičnost výuky, nedostatečný zájem žáků, nedostačující odborná vzdělanost učitelů, či momentální psychický stav jednotlivých žáků, atd.

Obr. 1: Kog. mapa-lepeni, archiv autora.

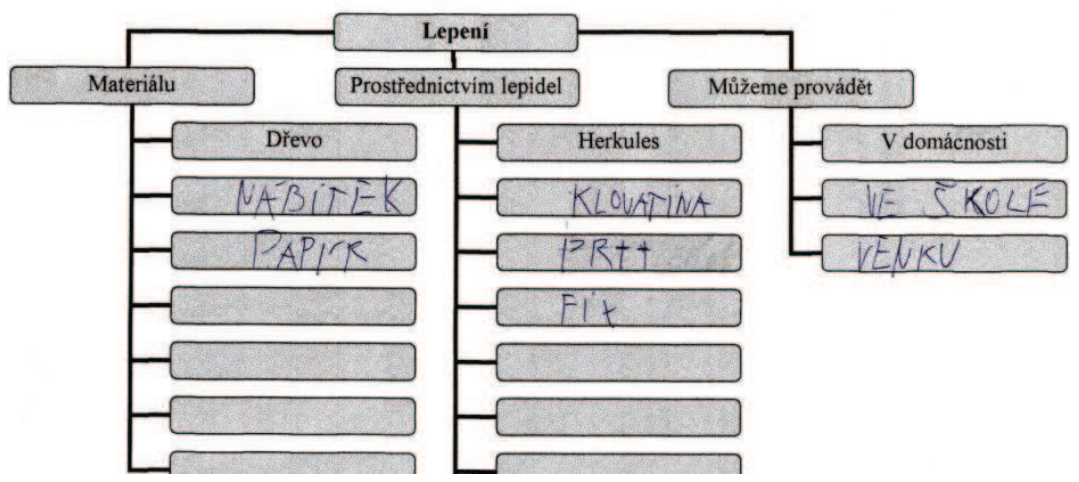


Mezi množstvím získaných odpovědí jsou zajímavé množstevní rozdíly. Třída 5.A, ZŠ Kubatova, uvedla v celkovém součtu 222 různých typů odpovědí při celkovém počtu 20 žákủ, třída 5.B téže školy, naproti tomu uvedla při celkovém počtu 18 žákủ 290 odpovědí a trrída 5.C, ZŠ Grünwaldovy, uvedla 218 odpovědí při celkovém počtu žáků 23. Na jednoho žáka z 5.A připadá 11,1 odpovědí, na žáka z $5 . B$ prripadá 16,1. odpovědí a na žáka z 5.C 9,47 odpovědí.

\section{Závěr}

$\mathrm{Na}$ základě provedeného výzkumu a zjištěných výsledů jsme dospěli $\mathrm{k}$ závěru, že je poněkud alarmující stav současné úrovně vzdělávání žáků v oblasti technické výchovy. Domníváme se, že by mělo dojít k celkové restrukturalizaci př́stupu učitele $\mathrm{k}$ technické výchově a jejím způsobu zařazení do výuky. Výuka by měla splňovat i cíle teoretické a afektivní, neomezovat se, jako doposud často, výhradně na cíle praktické. Jako zásadní, pro návrh strategie výuky, proto vidíme, aby byla výuka technické primární výchovy obecně důsledněji zaměřena na rozvoj kognitivních a afektivních cílů výuky, čímž bude žádoucím směrem rozšířen obzor, především $\mathrm{v}$ oblasti aktuálního vymezení technické gram. žáků.

\section{Literatura}

(1) MAREŠ, J. Výuka v „přebraných“ třídách očima psychologie. In Školský psychológ, ročník 9 , č. 1/2 , s. 4-15. ISSN 1212 - 0529. [cit. 200806-14]. Dostupné na www: $<$ http://www.lfhk.cuni.cz/mares/sp/index.htm>.

(2) ROUČOVÁ, E. Prekoncepty $k$ didaktice technické výchovy u studentù ucitelství pro primární školu. Nepublikovaná disertační práce. Olomouc: Pedagogická fakulta Olomouc, 2007. ISBN nemá.

(3) FISCHER, R. Učíme děti myslit a učit se. 1. vyd. Praha: Portál, 1997. 172 s, s. 71-72. ISBN 80-7178-966-6.

(4) BERTRAND, Y. Soudobé teorie vzdélávání. 1. vyd. Praha: Portál, 1998. 247 s, s. 71-72. ISBN 80-7178-216-5
(5) DOULÍK, P., ŠKODA, J. Reflexe nad základními aspekty konstruktivistického pojetí výuky $\mathrm{v}$ př́rodovědných předmětech. In Pedagogická revue, ročník 55a, číslo 5, s. 470482. ISSN 1335-1982.

(6) DOULÍK, P., ŠKODA, J. Tvorba a ověření nástrojů kvantitativní diagnostiky prekonceptů a možností jejího vyhodnocení. In Pedagogika, 2003b, roč. 52, č. 2, s. 177 - 189. ISSN 13351982.

(7) STUCHLÍKOVÁ, I. Úvod do psychologie emocí. 1. vyd. JCU v ČB: Ediční středisko PF ČB, 1998. 73 s. ISBN 80-7040-266-0.

(8) ČÁP, J., MAREŠ, J. Psychologie pro učitele. 1. vyd. Praha: Portál, 2001, 655 s, s. 433-436. ISBN 80-7178-463-X.

(9) BARTOŇ, A. Diagnostika vybraných prekonceptů k technické výchově žákỉ 5. tříd ZŠ. Nepublikovaná diplomová práce. České Budějovice: PdF JU, 2009.

(10) CHRÁSKA, M. Úvod do výzkumu $v$ pedagogice. 1. vyd. Olomouc: Univerzita Palackého, 2003. 199 s. ISBN 80-244-0765-5.

(11) KALHOUS, Z., OBST, O. Školni didaktika. 1. vyd. Praha: Portál, 2002. 447 s. ISBN 807178-253-X.

(12) ROUČOVÁ, E. Prekoncepty k didaktice technické výchovy u studentů učitelství pro primární školu. In Trendy technického vzdělávání. Praha: Votobia, 2005, s. 163-166. ISBN 80-7220-227-8.

(13) ROUČOVÁ, E. Pre-concepts of technical education didactics of students of teaching profession for the primary school. In Technika Informatyka - Edukacja.III.Miedzynarodowa Konferencja Naukowa. Rzeszóv: Uniwersytet Rzeszowski, 2005, s. 98-102. ISBN 83-88845$56-X$.

Mgr. Aleš Bartoň

Základní škola a Mateřská škola Strakonice

Plánkova 430, 38601 Strakonice

Česká republika

Tel.: +420 383332861

E-mail: bartonales @seznam.cz

http://zmskolast.webz.cz 